This item was submitted to Loughborough's Research Repository by the author.

Items in Figshare are protected by copyright, with all rights reserved, unless otherwise indicated.

\title{
Opinion: Inconvenient, or simply overlooked?
}

PLEASE CITE THE PUBLISHED VERSION

http://dx.doi.org/10.1177/1477153516658429

\section{PUBLISHER}

Sage / The Chartered Institution of Building Services Engineers

\section{VERSION}

AM (Accepted Manuscript)

\section{PUBLISHER STATEMENT}

This work is made available according to the conditions of the Creative Commons Attribution-NonCommercialNoDerivatives 4.0 International (CC BY-NC-ND 4.0) licence. Full details of this licence are available at: https://creativecommons.org/licenses/by-nc-nd/4.0/

\section{LICENCE}

CC BY-NC-ND 4.0

\section{REPOSITORY RECORD}

Mardaljevic, John. 2019. “Opinion: Inconvenient, or Simply Overlooked?”. figshare. https://hdl.handle.net/2134/22410. 


\title{
Inconvenient, or simply overlooked?
}

\author{
John Mardaljevic \\ School of Civil \& Building Engineering \\ Loughborough University \\ Loughborough, Leicestershire, LE11 3TU, UK
}

In a 1937 paper P. J. Waldram claimed that: "The eye is affected by ratio only, and is scarcely aware of huge variations in amount". Some of the evidence for this was based on an assessment of the daylight adequacy of 20 spaces carried out on both a "bright day" and a "dull day" by a 'jury' of six members. Waldram's claim led in part to what now appears to be an article of faith amongst a number of daylighting practitioners, i.e. that there is little or no need to make any consideration of absolute values - the daylight factor ratio is all that is required. Waldram's assertion and the evidence in support of it were examined in a 1955 CIE paper by R.O. Phillips of the N.S.W. University of Technology, Australia [1]. Phillips notes that: "If this investigation did, in fact, support the view that the daylight factor is more important than the actual illumination in determining the adequacy of the lighting, then the values of the daylight factor determined would be substantially the same on both types of day. If on the other hand, it is the illumination which is the more important, a higher value of the daylight factor would be required on a dull day than on a bright one".

The original report of the jury findings presented by Waldram included a single bell-shaped curve. This was intended to "summarise the results concisely and to deduce a figure of daylight factor which may fairly be said to represent the average opinion of the observers". Phillips decomposes this curve into the data taken on the bright and dull days respectively. They clearly show different distributions, with a marked preference for a higher daylight factor value on a dull day compared to a bright one: the means were $0.20 \%$ (dull day) and $0.09 \%$ (bright day). Applying a paired t-test on the data, Phillips notes that: "Since such a value could only arise by chance once in several millions of cases, the hypothesis that there is no difference must logically be rejected". In short, Phillips' analysis of the data makes the convincing case that, contrary to Waldram's assertion, the subjects were in fact expressing a preference for adequate absolute daylight levels rather than relative ones.

Phillips' paper is potentially of great significance since it offers a robust challenge to a rarely unquestioned assertion that has long been held as a fundamental tenet of daylighting science. That being so, a question presents itself: why has this paper been consigned to near-obscurity? The author's work was certainly not unknown. A search of the LR\&T / Trans IES database (1936 onwards) shows a paper published by Phillips in 1956, and a number of citations of his papers/books by other authors - but none for the 1955 paper. At the very least, this example invites us to reconsider some of the long-cherished notions of our profession - do they still hold? It should also encourage us to spend a little time searching the archives.

[1] R. O. Phillips. An historical outline of the concepts and terminology of daylight. Proc. CIE v2, Zurich, Switzerland, 1955. 